STUDI

FRANCESI

\section{Studi Francesi}

Rivista quadrimestrale fondata da Franco Simone

190 (LXIV | I) | 2020

Varia - fasc. I - gennaio-aprile 2020

\title{
MARIE-MADELEINE HUCHET, Une recomposition en prose de l'"Image du monde" de Gossuin de Metz
}

\author{
Maria Colombo Timelli
}

\section{(2) OpenEdition}

\section{Journals}

\section{Édition électronique}

URL : https://journals.openedition.org/studifrancesi/22337

DOI : $10.4000 /$ studifrancesi.22337

ISSN : 2427-5856

\section{Éditeur}

Rosenberg \& Sellier

\section{Édition imprimée}

Date de publication : 1 avril 2020

Pagination : 152-153

ISSN : 0039-2944

\section{Référence électronique}

Maria Colombo Timelli, " MARIE-MADeleINE HUChet, Une recomposition en prose de I"Image du monde" de Gossuin de Metz », Studi Francesi [En ligne], 190 (LXIV | I) | 2020, mis en ligne le 01 avril 2020, consulté le 03 août 2021. URL : http://journals.openedition.org/studifrancesi/22337 ; DOI : https://doi.org/ 10.4000/studifrancesi.22337

Ce document a été généré automatiquement le 3 août 2021

\section{(c) (i) (9) $\Theta$}

Studi Francesi è distribuita con Licenza Creative Commons Attribuzione - Non commerciale - Non opere derivate 4.0 Internazionale. 


\title{
MARIE-MADELEINE HUCHET, Une recomposition en prose de l'"Image du monde" de Gossuin de Metz
}

\author{
Maria Colombo Timelli
}

\section{RÉFÉRENCE}

MARIE-MADELEINE HUCHET, Une recomposition en prose de l'“Image du monde" de Gossuin de Metz, in “Romania” 135, 2017/3-4, pp. 393-411.

Le manuscrit Arsenal 2872, copié dans le Nord de la France entre 1425 et 1450, contient, parmi d'autres traités, une adaptation en prose de l'Image du monde de Gossuin de Metz. M.-M. H. identifie d'abord son modèle, à savoir la rédaction A de l'Image (1246, ca 6600 octosyllabes), pour souligner ensuite la méthode suivie par le compilateur, qui n'hésite pas à introduire des modifications dans le texte, voire dans l'ordre même des chapitres; le programme iconographique, quant à lui, subit surtout des simplifications. L'A. parvient aussi à cerner quelques informations sur l'auteur de cette mise en prose: d'une part, son intérêt pour la médecine ou la médecine astrologique, de l'autre sa provenance du domaine d'oc de la France, ce qui est confirmé surtout par certains traits linguistiques. Non moins intéressants, les liens qu'il établit entre son texte - qui occupe les ff. 22a-38a - et les autres œuvres contenues dans ce «manuscritbibliothèque», ainsi que le témoignage que son adaptation offre quant à la réception du traité de Gossuin auprès d'un lectorat noble du Xve siècle. 